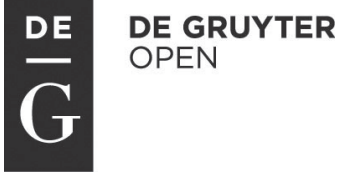

Przedsiębiorczość i Zarządzanie Entrepreneurship and Management University od Social Sciences Publishing House ISSN 1733-2486

Volume XVI, Issue 2, pp. 45-59

DOI 10.1515/eam-2015-0016

\author{
Mirosław Wypych \\ University of Social Sciences
}

\title{
Foreign Capital in Poland During Recession
}

\begin{abstract}
The system transformation which started in the last decade of the previous century and the accompanying transition into market oriented economy have contributed to the increase of foreign investors' interest in committing their capital in Poland. The interest grew even more after Poland joined the European Union. With limited national financial resources and great demand for the same, foreign investment has been a desirable factor supporting and accelerating economic growth.

The objective of this paper is to evaluate the changes in the level and structure of foreign capital in Poland in the years 2008-2013, that is during the period of economic downturn following the global financial crisis. The point is, first of all, to find an answer to the following question: to what extent has the economic destabilisation caused by the crisis influenced the decisions of foreign investors concerning investing their capital in Poland? This allows to verify the following scientific hypothesis: during crisis stability of the financial system of the country in which parent companies have their seats is more important for foreign investors than financial security of the host country. The analysis covers total foreign capital, that is both direct and portfolio investment, as well as derivatives and credit facilities. The empirical part of the study has been based on the information published by the National Bank of Poland.
\end{abstract}

Key words: foreign instruments, recession, economic growth, financial instruments

\section{Introduction}

The system transformation, which started in the last decade of the previous century, and the accompanying transition into market oriented economy have contributed to the increase of foreign investors' interest in committing their 
capital in Poland. The interest grew even more after Poland joined the European Union. With limited national financial resources and great demand for the same, foreign investment has been a desirable factor supporting and accelerating economic growth. It contributes, at the same time, to strengthening the competitive position of Poland on the international level. Apart from positive effects of the foreign capital impact on economy, however, the related threats should also be noticed. They are connected for example with the fact that part of foreign investment has a speculative character. This may result in fluctuations in the level and structure of foreign investment, depending on the economic situation in global markets. Similarly to other Eastern European countries Poland is perceived by foreign investors as a territory with high investment risk. During escalation of crisis speculative investment is withdrawn from such countries in the first place which results in specific repercussions on the entire economy.

The objective of this paper is to evaluate the changes in the level and structure of foreign capital in Poland in the years 2008-2013, that is during the period of economic downturn following the global financial crisis. The point is, first of all, to find an answer to the following question: to what extent has the economic destabilisation caused by the crisis influenced the decisions of foreign investors concerning investing their capital in Poland? This would allow to verify the following scientific hypothesis: during crisis foreign investors believe that stability of the financial system of the country in which parent companies have their seats is more important than financial security of the host country where subsidiaries are located. The analysis covers total foreign capital, that is both direct and portfolio investment, as well as derivatives and credit facilities. The empirical part of the study has been based on the information published by the National Bank of Poland.

\section{Symptoms of recession}

The basic macroeconomic indicators describing Polish economy after 2007 clearly indicate that we have to do with a destabilisation of conditions of the functioning of business entities. No GDP decrease has been recorded, just a slowdown of its growth rate, and therefore in economic terms there has been no crisis but only a recession. In the light of the data presented in table 1 it is perfectly clear that economic downturn in Poland has been a consequence of the global financial crisis which began in the second half of 2007 in the United States after which it swept through most countries of the world, in particular the highly developed ones. Its effects left a mark on global economy, from the point of view of both micro- and macroeconomics, as well as on capital flows. 
In the present-day world economy there are very close interrelations among individual countries and any changes in the economic situation of one country influence other states. The relations between Polish economy and global commodity and capital markets have made it impossible for our country to avoid the consequences of the financial crisis. 


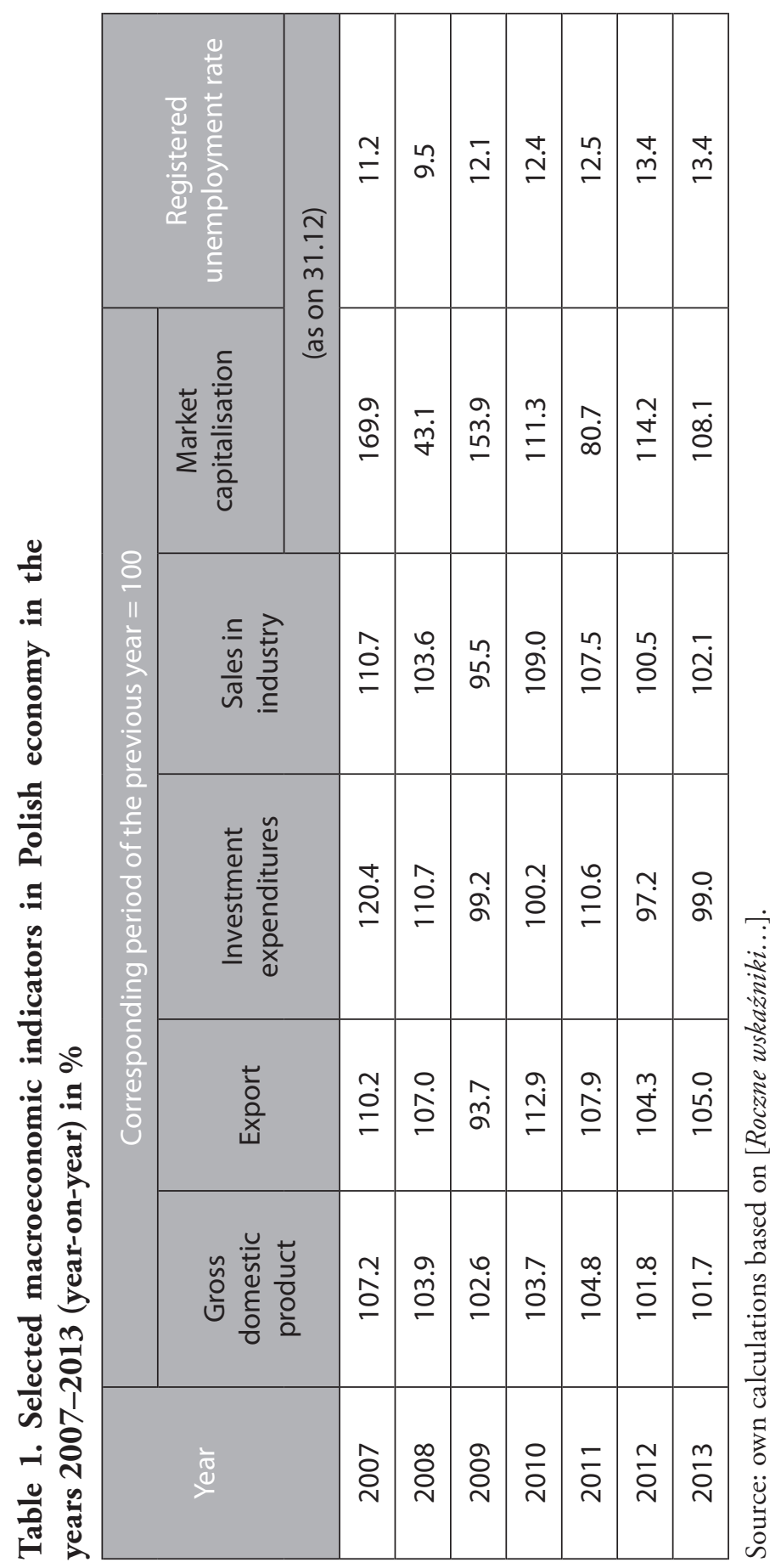


The GDP dynamics in 2008 decreased significantly when compared to 2007. The same applied to export, capital expenditures and sales in industry. The consequences of recession impacted in the first place and to the greatest extent the capital market (Warsaw Stock Exchange). The value of shares listed on the Warsaw Stock Exchange decreased in 2008 when compared to the previous year by nearly $57 \%$, whilst in the subsequent years the dynamics of market capitalisation was characterised by considerable changeability. What is surprising here is the decrease of registered unemployment rate from $11.2 \%$ in 2007 to $9.5 \%$ in 2008 (it has been the lowest level from the beginning of system transformation).

In 2009 the value of export, capital expenditures and sales in industry was lower than a year before. The improvement of situation in subsequent years was temporary. Fluctuations in the dynamics of industrial production and capital expenditures may suggest that production powers in enterprises was not used to the full, which, in turn, ended in the lack of interest in creation of new jobs. As a result the unemployment rate shows a growing tendency [Wypych 2014, p. 667].

\section{Foreign capital as a development factor}

When describing foreign capital in national economy, it should be clearly underlined that it has different forms. It is commonly assumed that the main ones include direct and portfolio investment. From the point of view of impact of foreign investment on the efficiency of economy, and in particular industry, it is assumed that the former is of fundamental importance, since portfolio investment has to a large extent a speculative character whilst its scale depends mainly on interest rate changes. Portfolio investment does not have any significant impact on structural transformations of national economy and its competitiveness but is used mainly to finance the budget deficit and, to a certain extent, determine the development of exchange market. Both direct and portfolio investment includes two types of financial instruments, that is equity instruments (shares and other forms of equity) and debt instruments (debt securities).

The important thing in the case of direct investment is a legal aspect of investing capital by foreign investors. According to the provisions of the Act on companies with foreign capital participation of 14 June 1991 (Dz. U. of 1991, No. 60 item 253 as amended) a foreign entity may run its business activity on its own behalf (direct activity) or participate in the running and results of such activity run by a domestic entity (indirect activity). A foreign entity may run a business activity only in the form of a limited liability com- 
pany (spótka zograniczona odpowiedzialnościa) or joint stock company (spótka akcyjna). This means that these may be companies with foreign participation only, or mixed companies. The decisive and only fact which determines whether a given company is a company with foreign participation is whether any foreign entity holds some of its shares. The actual value of participation of a foreign entity in the share capital of a company is of no importance here, however the degree of capital participation of a foreign investor determines the extent of its control over the company - it is, however, a problem of an ownership supervision.

In the case of portfolio investment no active control over the issuer of securities is involved and investors settle for realisation of profit. Profit is generated on the basis of differences in interest rates or currency fluctuations. For this reason the decisions of investors interested in securities are most usually grounded on credit rating of a given country. The rating is prepared by independent financial organisations (rating agencies) and its purpose is to establish the risk connected with a given state. No security issued by an authorised entity in a given country may have higher rating than the bonds issued by the government of such a country. Portfolio investment plays an important part in financing budget deficit since a considerable part of treasury bonds is purchased by foreign investors.

Apart from direct and portfolio investment foreign capital includes such instruments as trade credits (connected with deferred payments and advance payments in export and import transactions), loans and borrowings from equity-related entities, funds in cash and bank accounts owned by a foreign entity and deposited in the receiving country, etc. (they are described as "other investment"). Furthermore, derivatives, which are not securities and whose value depends on the underlying asset such as, for example, share price, bond yield, interest rate, exchange index, etc., are a separate and specific category of foreign capital. Derivatives fall into two categories: symmetric instruments (forwards, various types of exchange transactions) and asymmetric instruments (options) [Międzynarodowa pozycja..., 2013, pp. 49-50].

The most important facts which prove a positive impact of foreign investment in Poland include participation in financing of budget deficit, increase of capital expenditures, imitation effect, employment growth, improving the qualifications of employees of enterprises with foreign capital participation, technological progress, export increase, increase of cooperation with domestic companies. Furthermore, foreign investment stabilises the balance of payments and exchange rate [Wyżnikiewicz 2001, p. 7, Rzepka 2005, p. 52, Wieczorek 2005 , p. 77]. Negative consequences of the impact of foreign capital include 
attempts to evade paying taxes, slight tendency to reinvest profits, low proportion of greenfield type investment (constructed from the ground up), high share of supply import, lack of inclination for research and development activity [Prusek 2005, p. 86, Kotula 2004, p. 28, Pawłowicz 2008, pp. 13-18, Wypych 2007, pp. 468-469].

\section{Dynamics and structure of foreign capital in the years 2008-2013}

The level of the foreign capital invested in Poland expressed in absolute terms in the years 2004-2013 nearly tripled (from 638 billion PLN to 1,840 billion PLN). In the period covered by the analysis (2008-2013) there was a $60 \%$ increase which means that macroeconomic destabilisation resulted for example in a slowdown in the inflow of foreign capital to the Polish economy. The information on the dynamics of foreign investment, taking into account its generic structure, is presented in table 2.

Table 2. Dynamics of foreign investment in the years 2008-2013 taking into account its types

\begin{tabular}{|l|c|c|c|c|c|c|}
\hline \multicolumn{1}{|c|}{ Item } & $\mathbf{2 0 0 8}$ & $\mathbf{2 0 0 9}$ & $\mathbf{2 0 1 0}$ & $\mathbf{2 0 1 1}$ & $\mathbf{2 0 1 2}$ & $\mathbf{2 0 1 3}$ \\
\hline $\begin{array}{l}\text { Direct investment, in } \\
\text { which }\end{array}$ & 111.8 & 108.7 & 126.3 & 105.6 & 105.1 & 104.8 \\
\hline - equity investment & 107.1 & 109.3 & 121.7 & 99.4 & 107.0 & 104.9 \\
\hline - debt investment & 126.0 & 106.9 & 138.3 & 119.9 & 101.4 & 104.3 \\
\hline $\begin{array}{l}\text { Portfolio investment, in } \\
\text { which }\end{array}$ & 90.3 & 126.2 & 133.4 & 110.7 & 122.0 & 100.2 \\
\hline - equity investment & 59.2 & 136.8 & 152.0 & 87.6 & 132.6 & 110.5 \\
\hline - debt investment & 105.3 & 123.5 & 128.0 & 118.6 & 119.3 & 97.4 \\
\hline $\begin{array}{l}\text { Other investment, in } \\
\text { which }\end{array}$ & 142.7 & 105.2 & 105.0 & 114.6 & 92.3 & 103.0 \\
\hline - trade credits & 119.1 & 98.3 & 95.6 & 122.4 & 88.6 & 101.5 \\
\hline - loans and borrowings & 148.7 & 103.5 & 104.5 & 118.0 & 96.7 & 100.3 \\
\hline - cash & 140.1 & 105.5 & 120.6 & 103.0 & 76.7 & 108.1 \\
\hline Derivatives & 342.8 & 29.7 & 457.1 & 136.0 & 89.5 & 83.5 \\
\hline Total foreign capital & $\mathbf{1 1 5 . 8}$ & $\mathbf{1 1 0 . 0}$ & $\mathbf{1 2 2 . 1}$ & $\mathbf{1 0 9 . 8}$ & $\mathbf{1 0 5 . 3}$ & $\mathbf{1 0 2 . 7}$ \\
\hline
\end{tabular}

Source: own analysis based on Międzynarodowa pozycja... 
In the first place it should be emphasised that along with the entire period we can see a positive dynamics of value of the total foreign capital. It applies also to direct investment. In the case of portfolio investment a slump was recorded only in 2008 ( $10 \%$ drop when compared to the previous year), that is in the beginning of the recession. Also the next slowdown phase made itself felt: the level of portfolio investment in 2013 did not change with respect to 2012. There were, however, fluctuations in the case of other investment (drop in 2012), in particular in the case of derivatives. Derivative instruments are associated with high risk and therefore they are very sensitive to any changes in the level of macroeconomic indicators such as interest rates, exchange rates or share prices.

It is also very clear that fluctuations in the dynamics of direct investment are less considerable than in the case of portfolio investment, whereas fluctuations in the dynamics of equity investment are larger than in the case of debt investment. This results from the specific character of financial instruments: shares involve higher risk than bonds. The structure of foreign direct investment is dominated by equity instruments (over 2/3), whereas the structure of portfolio investment - by debt instruments (over 3/4). The legitimacy of the hypothesis presented in the beginning is most clearly visible with respect to other investment. Limitation of the degree of crediting and cash in the years 2009 and 2012 is directly related to recession phenomena observed in the countries from which majority of investment getting to Poland comes (Germany, France, the Netherlands).

The next two tables present the information concerning the structure of foreign investment. Table 3 lists the main types of foreign investment, whereas table 4 - the basic financial instruments reflecting foreign capital.

Table 3. Structure of foreign capital in Poland in the years 2008-2013 by type (\%)

\begin{tabular}{|l|c|c|c|c|c|c|}
\hline \multicolumn{1}{|c|}{ Item } & 2008 & 2009 & 2010 & 2011 & 2012 & 2013 \\
\hline Total foreign capital & 100.0 & 100.0 & 100.0 & 100.0 & 100.0 & 100.0 \\
\hline Direct investment & 44.3 & 43.7 & 45.2 & 43.5 & 43.4 & 44.3 \\
\hline Portfolio investment & 20.0 & 22.9 & 25.0 & 25.3 & 29.3 & 28.5 \\
\hline Other investment & 34.6 & 33.1 & 28.6 & 29.8 & 26.2 & 26.2 \\
\hline Derivatives & 1.1 & 0.3 & 1.2 & 1.4 & 1.1 & 1.0 \\
\hline
\end{tabular}

Sources: as in the case of table 2. 
Direct investment and equity instruments are of greatest importance. From the point of view of economy such a situation is very advantageous since both direct investment and equity instruments are relatively stable. It is due to the fact that investing capital in such a form involves long-term decisions. Profitability of such investment is determined by the following factors: prospects for the increase of national demand, market size, value and competitive position of enterprises in which capital is invested. If the economic situation of the host country and conditions of running business activity deteriorate, it is much harder to withdraw the capital involved in direct investment and equity instruments. In such a case investors are forced to take restructuring measures to minimise losses while trying, at the same time, to earn profit anyway [Konieczny, Wypych 2006, p. 265].

\section{Table 4. Structure of foreign capital by financial instruments in the years 2008-2014}

\begin{tabular}{|l|c|c|c|c|c|c|}
\hline \multicolumn{1}{|c|}{ Share } & 2008 & 2009 & 2010 & 2011 & 2012 & 2013 \\
\hline Equity instruments & 35.9 & 36.7 & 37.2 & 33.5 & 35.3 & 36.5 \\
\hline $\begin{array}{l}\text { Debt instruments, in } \\
\text { which }\end{array}$ & 28.4 & 30.0 & 32.4 & 35.2 & 37.3 & 36.2 \\
\hline - bonds and treasury bills & 14.6 & 16.5 & 18.4 & 20.1 & 23.0 & \\
\hline Trade credits & 4.3 & 3.8 & 3.1 & 3.3 & 2.8 & 2.8 \\
\hline Loans and borrowings & 22.6 & 21.2 & 18.5 & 19.6 & 18.0 & 17.3 \\
\hline $\begin{array}{l}\text { - in which government } \\
\text { loans }\end{array}$ & 2.9 & 3.3 & 3.2 & 3.7 & 3.6 & \\
\hline Cash & 7.5 & 7.3 & 7.2 & 6.7 & 4.9 & 5.1 \\
\hline
\end{tabular}

Sources: as in the case of table 2.

What should be underlined is the increased share of treasury debt instruments (mainly treasury bonds) and government loans in the total value of foreign capital. The value of the bonds issued by the State Treasury and owned by foreign investors amounted in 2000 to 37.6 billion PLN and increased to 108.3 billion PLN in 2004 (Poland's accession to the EU) and exceeded 400 billion PLN in 2012. The data include the bonds issued both in Poland and abroad. The value of loans and borrowings, on the other hand, granted to the government sector changes depending on the current demand: for example in 2004 it amounted to 64.2 billion PLN, in 2008 to 32.7 billion PLN and 
in 2012 to 62.6 billion PLN. In 2013 treasury bonds made up $97.7 \%$ of all bonds owned by foreign investors. Thus foreign investment contributes significantly to the financing of budget deficit despite the fact that at the same time it is reflected in the national debt. Poland's sovereign debt as at the end of 2013 in relation to foreign capital was $62.5 \%$, whilst participation of government sector in sovereign debt amounted to 40.2\% [Międzynarodowa pozycja..., 2014, p. 27].

\section{Recession versus foreign direct investment}

Analysis of the dynamics and structure of foreign capital does not provide a complete answer to the question posed in the beginning, since it is based on the information on the situation at the end of every year. Changes in the investment level at year end take into account investment inflows and outflows. It seems that we may get a more reliable picture of relationships between the economic downturn and investment on the basis of the analysis of inflow and outflow of foreign direct investment. As it has been indicated earlier foreign direct investment is more stable and more than other elements of foreign capital connected with the host country economy. Foreign direct investment occurs at the same time in three areas: of international transfer of capital, specialist expertise in management and new technologies and enterprise. Access to new technologies, new forms of management and production organisation contributes to modernisation and improved functioning of local enterprises. In the case of direct investment additional elements, such as unearned income and scope of reinvestment of profits, may be taken into account additionally.

Table 5 presents global information concerning capital flows connected with foreign direct investment with particular attention paid to European Union and Poland. 


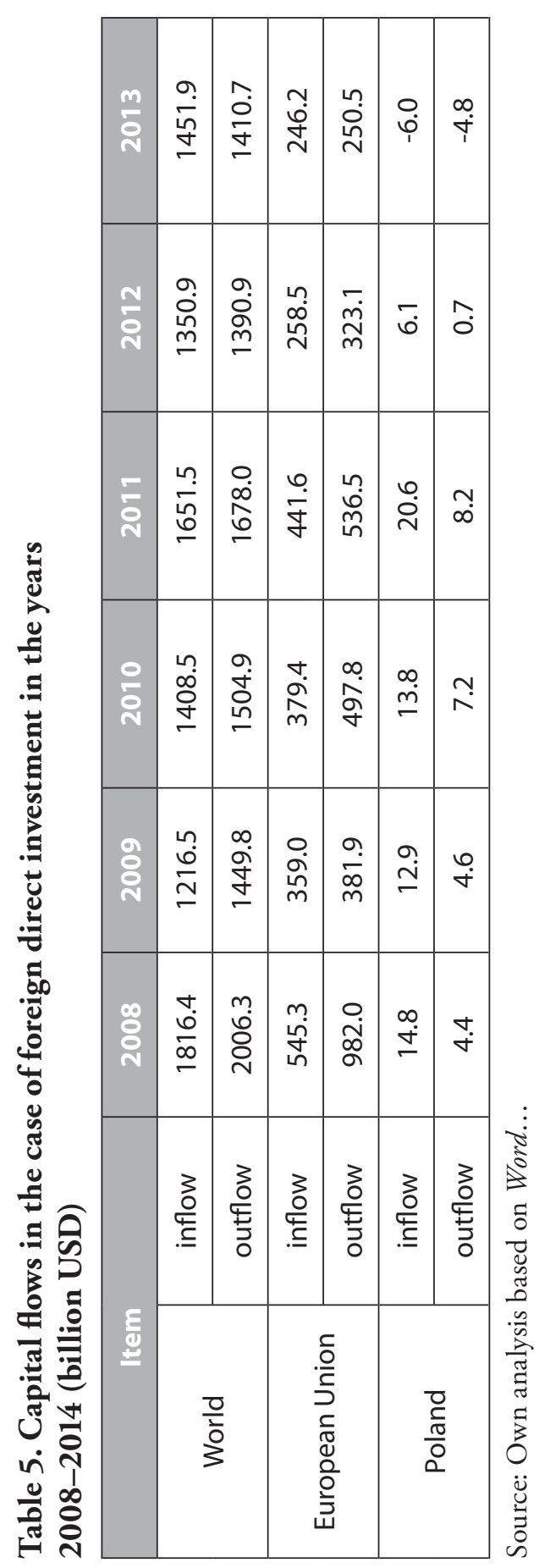


Impact of the financial crisis on the level of foreign direct investment is quite clearly noticeable. Both in the world and in the European Union the outflow of the capital related to direct investment in the years 2008-2012 is greater than capital inflow, whereas in the European Union the disproportions are greater. In 2013 global capital inflow for the first time slightly exceeded capital outflow. The situation in Poland looks different. In the years 20082013 there was a constant and clear advantage of investment inflow over investment outflow, whereas in 2011 a record level of inflow of foreign direct investment was seen (over 20 billion dollars). In 2012 capital outflow was at the minimum level whilst in 2013 a paradoxical situation arose in Poland the values of both capital inflow and outflow were negative. What contributed to it was a large scale of the so-called capital in transit. It includes transactions of special purpose vehicles which transfer funds between countries at a request of a parent corporation and for the purpose of tax optimisation. This is one of the consequences of global crisis and it confirms legitimacy of the hypothesis presented in the introduction.

This means that during recession Poland was an attractive country to investors. According to the report of Ernst \& Young Poland is a leader in respect of investment increase in Europe. In 2012 it recorded the highest rise in the number of investment projects among European countries $(22 \%$ more than in 2011), whilst Europe recorded a $2.8 \%$ decrease. Foreign direct investment contributed to the creation of $67 \%$ more jobs than in the previous year (the result for the entire Europe is $+8 \%$ ). The report placed Poland in the first place in the region of Central and Eastern Europe as regards investment competitiveness. Also in 2013, in the European attractiveness survey conducted by Ernst \& Young, Poland took the first place in Central and Eastern Europe as the most attractive country in the region [Atrakcyjnośc inwestycyjna ...]

Revenue from foreign direct investment is an important issue from the point of view of the hypothesis formulated above. Relevant information is presented in table 6. 


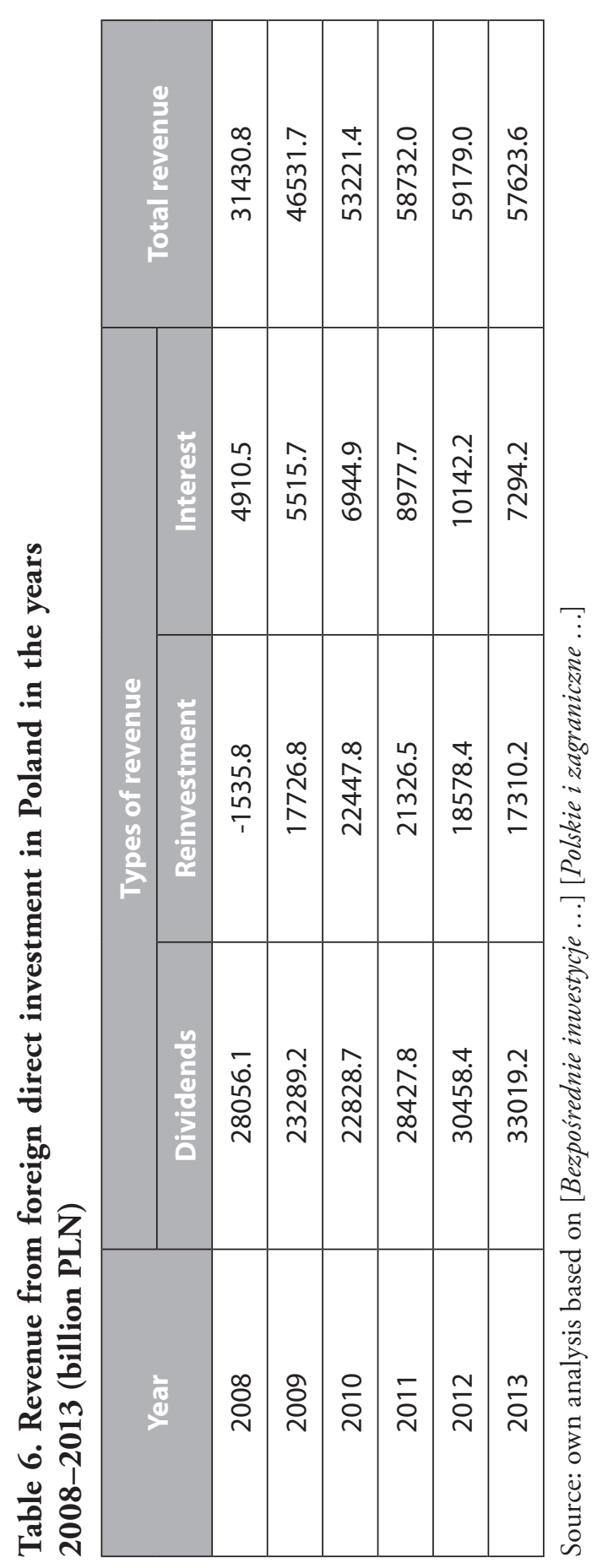


Economic destabilisation has not contributed to reduction of total revenue earned by foreign investors. On the contrary, a tendency for its increase can be observed. On the other hand, the structure of revenue has changed. The level of paid dividends and received interest has grown, whereas the value of retained profit has decreased since 2011. This means an outflow of capital from Poland. Such situation has been caused by a limited access to attractive investment projects on the one hand, whilst on the other hand by deliberate actions the purpose of which is to supply capital to parent corporations with their seat abroad through the agency of the subsidiaries located in Poland.

\section{Summary}

During recession caused by the global financial crisis Poland has been perceived as an attractive country to foreign investors. This finds its confirmation in the data concerning fluctuations in the value of capital flowing in from abroad after 2008. Foreign capital completes insufficient accumulation of Polish economy. Besides, foreign investment plays an important part in the financing of budget deficit. Despite the fact that it finds a reflection in a high level of Poland's debt, such a situation should be evaluated positively. What should be emphasised in the first place is a relatively high participation of foreign direct investment which is more stable than other types of foreign capital.

Analysis of structure of foreign capital broken down by type and of revenues from foreign direct investment proves, at the same time, legitimacy of the hypothesis presented in the beginning according to which during crisis financial stability of the country in which parent companies have their seats is more important for foreign investors than financial security of the host country. This finds its confirmation in an intensification of transactions of the so-called special purpose vehicles, upward trend in the level of dividends and interest paid to foreign investors and downward trend in the level of profit reinvestment.

\section{References}

Atrakcyjność inwestycyjna Europy, (2013), (2014), Ernst \& Young Polska report, Warsaw.

Kotula M. (2004), Ceny transferowe w podatkowej grupie kapitatowej, "Ekonomika i Organizacja Przedsiębiorstwa”, no. 6.

Konieczny, Z., Wypych M. (2008), Inwestycje zagraniczne na polskim rynku gietdowym w latach 2003-2005 [in:] Finanse i bankowość w integrującej się Unii Europejskiej, (ed.) T. Famulska, J. Nowakowski, Difin, Warsaw. 
Międzynarodowa pozycja inwestycyjna Polski w 2013 roku, (2014), NBP, Warsaw.

Pawłowicz L. (2006), Nowy wymiar globalnego kryzysu finansowego [in:] Zarzadzanie wartościa przedsiębiorstwa w warunkach zaktóceń na rynkach finansowych, ed. J. Bieliński, M. Czerwińska, Fundacja Rozwoju Uniwersytetu Gdańskiego, Sopot. Polskie i zagraniczne inwestycje bezpośrednie (2014), NBP, Warsaw.

Prusek A. (2005), Prywatyzacja polskiej gospodarki. Cele, programy i ocena jej rezultatów, Cracow University of Economics, Kraków.

Roczne wskaźniki makroekonomiczne - Website of the Central Statistical Office of Poland www.stat.gov.pl.

Rzepka A. (2005), Inwestycje zagraniczne a globalizacja gospodarki, "Ekonomika i Organizacja Przedsiębiorstwa”, no. 1.

Wieczorek P. (2005), Bezpośrednie inwestycje zagraniczne w Polsce $i$ na świecie, "Wiadomości Statystyczne", no. 12.

Word Investment Report 2013, Non-Equity Modes of International Production and Development (2014), UNCTAD.

Wypych M. (2007), Pozycja konkurencyjna spótek gietdowych kontrolowanych przez inwestorów zagranicznych, "Prace Naukowe AE we Wrocławiu", no. 1159.

Wypych M. (2014) Równowaga finansowa przedsiębiorstw przemystowych w okresie spowolnienia gospodarczego, "Zeszyty Naukowe Politechniki Śląskiej, Organizacja i Zarządzanie", Z. 73.

Wyżnikiewicz B. (2001), Korzyści z obcego kapitatu, "Prawo i Gospodarka", no. 54.

Zagraniczne inwestycje bezpośrednie w Polsce (2009-2015), Cykliczne materiały statystyczne NBP, NBP, Warsaw. 